\title{
Intra-regional Trade Effects of ASEAN Free Trade Area in the Textile and Clothing Industry
}

Mohammed Faiz Shaul Hamid

University of Malaya, Malaysia

Mohamed Aslam

University of Malaya, Malaysia

\begin{abstract}
This study investigates intra-regional trade effects of the ASEAN Free Trade Area in the textile and clothing industry by focusing on trade competitiveness and complementarities. Using a novel method of investigating intra-regional trade through 20 bilateral pairs of ASEAN countries, the study analyzed 1,040 observations at the HS3 level to determine revealed comparative advantage and intra-industry trade. The results for both revealed comparative advantage and intra-industry trade in the context of the textile and clothing industry show that most ASEAN countries compete predominantly in trade of unprocessed products or raw materials. Consumer or finished products do not exhibit a high degree of competition, which suggests that product diversification has enabled ASEAN countries to actively export to the global market. The results also show trade-creating and trade-diverting effects in a number of products categories, categories, suggesting that this divergence may disrupt ASEAN's vision of becoming a regional hub for the textile and clothing industry.
\end{abstract}

JEL Classifications: F14, F15, F19

Keywords: AFTA, Intra-regional Trade, ASEAN Textile Industry

\footnotetext{
* Corresponding Author: Mohammed Faiz Shaul Hamid; University of Malaya, Kuala Lumpur, Malaysia, Email: faiz.shaul@gmail.com Co-Author: Mohamed Aslam; University of Malaya, Kuala Lumpur, Malaysia, Email: maslam@um.edu.my
} 


\section{Introduction}

The textile and clothing industry plays a vital role in the economies of Association of South East Asian Nations (ASEAN) countries. Today, some ASEAN countries are particularly well-known producers and exporters of textiles and clothing in the world. The success of this industry within the region raises several questions regarding the impact of ASEAN through the ASEAN Free Trade Agreement (AFTA) and regional integration efforts that may have greatly contributed to the industry's advancement.

The textiles and clothing industry is unique in that involves production of textiles and clothing that undergo value addition in many stages of production. In general, it involves processing raw materials as well as design, assembly, and production of finished goods. Usually, different stages of production are carried out in different regions or countries, with the supply chain spanning the globe. The stages of production require different factor endowments, technology, and supporting systems. As an industry, textile and clothing production is commonly based on demand from developed countries. Developing countries specialize in the value chain activities, especially those based on the common factor of cheaper labor.

Countries in ASEAN have come a long way in the process of trade liberalization through AFTA. Since AFTA's establishment in 1993 and eventually the ASEAN Economic Community's creation in 2015, many efforts, not only in tariff elimination and reduction but also in integrating industry-focused efforts aimed at eliminating nontariff barriers, have been made. As a result, as shown in Table 1, the value of ASEAN5(Malaysia, Thailand, Indonesia, Philippines and Vietnam)'s exports of textile and clothing products nearly tripled from 24.4 billion US dollars in 2001 to 71.8 billion US dollars in 2014. Although the value of these exports increased dramatically, the share of exports remained in the range of $9 \% \sim 10 \%$ of textile industry activity 2005 onwards, mostly due to the rapid increase in value for all of ASEAN-5 product exports.

Based on country-level values, ASEAN-5 exports in the textile and clothing industry are presented in Table 2 and Figure 1 below. Although a general trend of increase in value occurred during 2001 2014 for all countries except the Philippines, the value recorded by Vietnam belongs to a completely different category. Vietnam's exports rose from 3.8 billion US dollars in 2001 to 40.6 billion US dollars for the same period. This amounts to a more than 10-fold increase in value, as shown in Figure 1 below. Vietnam's overtaking of other ASEAN countries after 2005 can be seen also as a normalization 
effect of values for other ASEAN countries. Specifically, other ASEAN countries did not see growth in export values after the emergence of Vietnam as the top exporter of textile and clothing. This particular effect is due to Vietnam's accession to the World Trade Organization (WTO) in year 2007, allowing it to export to larger markets at better tariffs.

Table 1. Share of textile and clothing industry in ASEAN countries

(Thousand US dollars, 2001 2014)

\begin{tabular}{|l|c|c|c|c|c|}
\hline & $\mathbf{2 0 0 1}$ & $\mathbf{2 0 0 5}$ & $\mathbf{2 0 0 8}$ & $\mathbf{2 0 1 1}$ & $\mathbf{2 0 1 4}$ \\
\hline $\begin{array}{l}\text { Total Exports } \\
\text { of ASEAN-5 }\end{array}$ & $24,385,026$ & $31,793,894$ & $37,690,297$ & $55,177,235$ & $71,759,100$ \\
\hline $\begin{array}{l}\text { All Products export } \\
\text { for ASEAN-5 }\end{array}$ & $191,881,734$ & $328,867,192$ & $412,035,935$ & $611,760,305$ & $691,135,682$ \\
\hline $\begin{array}{l}\text { Share of Textile } \\
\text { and Clothing } \\
\text { Exports }\end{array}$ & $13 \%$ & $10 \%$ & $9 \%$ & $9 \%$ & $10 \%$ \\
\hline
\end{tabular}

(Source) Author's own illustration of UN Comtrade data.

Table 2. Exports of the textile and clothing industry

(Thousand US dollars, 2001 2014)

\begin{tabular}{|l|c|c|c|c|c|}
\hline $\begin{array}{l}\text { ASEAN-5 } \\
\text { Countries }\end{array}$ & $\mathbf{2 0 0 1}$ & $\mathbf{2 0 0 5}$ & $\mathbf{2 0 0 8}$ & $\mathbf{2 0 1 1}$ & $\mathbf{2 0 1 4}$ \\
\hline Malaysia & $2,387,187$ & $2,799,730$ & $3,223,696$ & $3,738,460$ & $3,555,134$ \\
\hline Thailand & $6,154,507$ & $7,655,345$ & $8,202,853$ & $9,311,883$ & $8,351,972$ \\
\hline Indonesia & $9,208,361$ & $10,063,179$ & $12,054,495$ & $16,582,753$ & $16,875,587$ \\
\hline Philippines & $2,694,461$ & $2,589,197$ & $2,237,298$ & $1,624,200$ & $2,174,932$ \\
\hline Vietnam & $3,839,886$ & $8,485,017$ & $15,115,220$ & $23,630,922$ & $40,587,015$ \\
\hline
\end{tabular}

(Source) Author's own illustration of UN Comtrade data. 


\section{Figure 1. Exports of the textile and clothing industry in ASEAN}

(Thousand US dollars, 2001 2014)

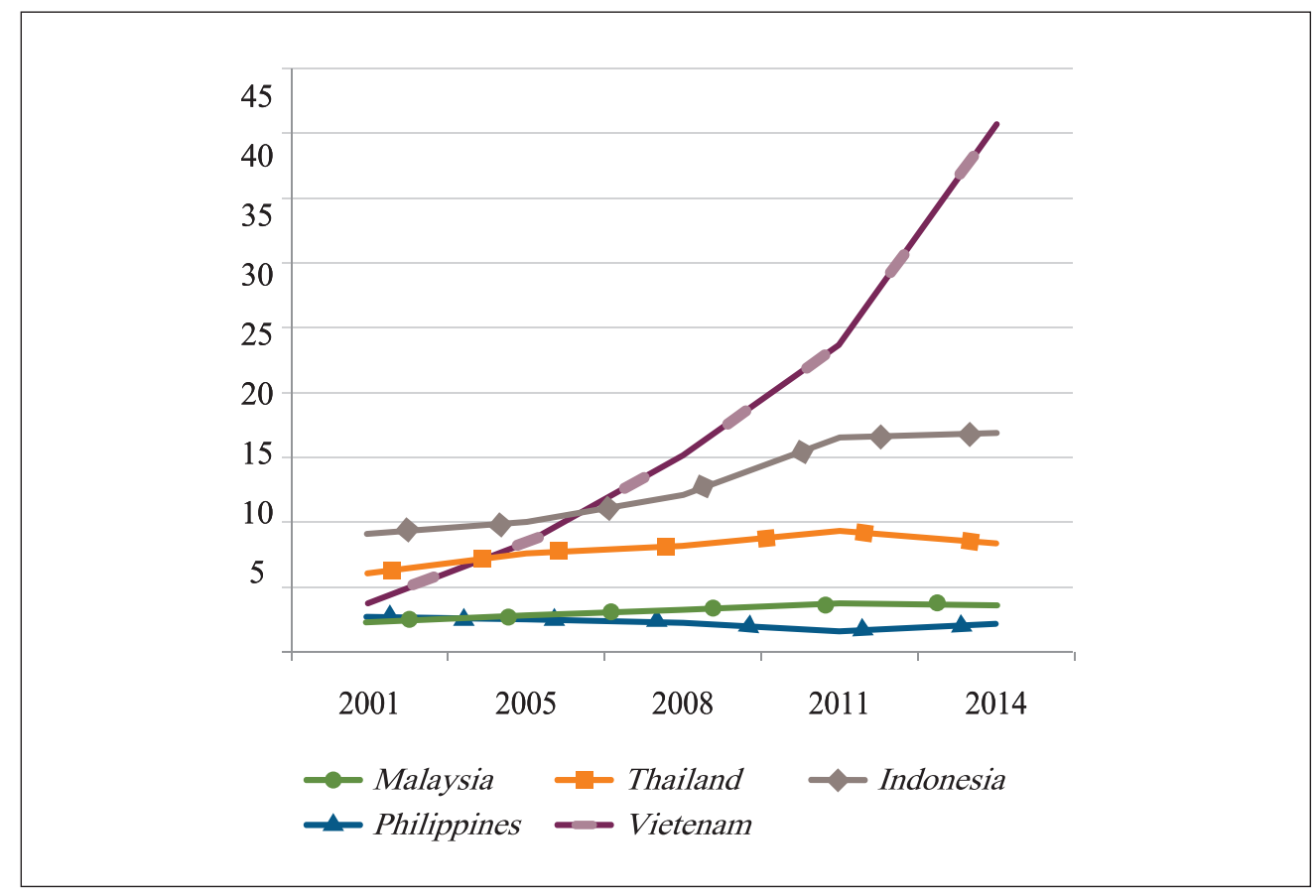

(Note) Export value for the textile industry is based on HS3 level data classification of products HS430,500,510,511,5 20,521,530,531, 540, 550, 551, 560, 570, 580, 581, 590, 591, 600, 610, 611, 620, 621, 630, 631, 640, and 650. (Source) ASEAN Statistics Database, http://www.aseanstats.org/

Apart from the country-level export values, the top five product categories having the highest exports from ASEAN-5 countries are shown in Table 3. Aside HS540 manmade filaments yarn and synthetic yarn, all other top five products are finished products. This implies that the collective values of products exported by ASEAN-5 countries are dependent on those four finished product categories. Although man-made filaments yarn and synthetic yarn did not record as high a value as the four finished products, it has broader importance for some ASEAN countries.

The ASEAN textile and clothing industry consists mainly of production of manmade filaments yarn and synthetic yarn and fabrics; these are produced in one ASEAN country, and then shipped to another ASEAN country to be made into a finished product. ASEAN's integration in the textile and clothing industry indicates a comprehensive 
integration of textiles and clothing industry with all elements of the supply chain spread across several ASEAN members, such as production of fibers, spinning of yarns, knitting or weaving of fabrics, and cutting and sewing of finished apparel, as well as at least some regional integration into global supply chains (George Siy 2007).

\section{Table 3. Top 5 product items in HS3 exported by ASEAN-5}

(Thousand US dollar, 2001 2014)

\begin{tabular}{|l|l|c|c|c|c|}
\hline $\begin{array}{l}\text { HS } \\
\text { Code }\end{array}$ & Product Category & $\mathbf{2 0 0 1}$ & $\mathbf{2 0 0 5}$ & $\mathbf{2 0 0 8}$ & $\mathbf{2 0 1 4}$ \\
\hline 620 & $\begin{array}{l}\text { Women and man: } \\
\text { overcoat, jacket, dresses, }\end{array}$ & $6,652,898$ & $8,046,358$ & $9,403,845$ & $11,401,799$ \\
\hline 640 & Footwear & $4,133,863$ & $5,558,785$ & $7,949,057$ & $11,162,334$ \\
\hline 610 & $\begin{array}{l}\text { Women and man: } \\
\text { coat, jacket, suits, } \\
\text { undergarments, knitted/croch etc }\end{array}$ & $2,836,068$ & $4,689,279$ & $6,770,458$ & $8,251,607$ \\
\hline 611 & $\begin{array}{l}\text { Jerseys, babies garments, } \\
\text { track suits, swimwear }\end{array}$ & $2,199,143$ & $2,370,714$ & $3,570,276$ & $4,808,750$ \\
\hline 540 & $\begin{array}{l}\text { Man-made: filaments yarn } \\
\text { and synthetic }\end{array}$ & $2,078,362$ & $2,539,096$ & $2,746,910$ & $3,881,364$ \\
\hline
\end{tabular}

(Source) Author's own illustration from UN Comtrade data.

In envisioning such a level of integration, ASEAN embarked on the ASEAN Roadmap for Integration of Textiles and Apparel Products Sector (ARITAP). ARITAP covered the full textile and clothing supply chain, including raw fibers (raw cotton, wool, and polyester staple fibers), yarns, fabrics, and finished apparel or textile articles. It also provided for the elimination of tariffs on intra-ASEAN trade in all sector products, as well as other measures to encourage integration. Removal of global quotas also had a larger influence on the degree of production integration among ASEAN countries compared to the tariff eliminations and reductions mandated in ARITAP. The lifting of these quotas under the WTO Agreement on Textiles and Clothing (ATC) on January 1,2005 , enormously increased competition among global suppliers to the US and EU markets, including ASEAN countries. 
ASEAN's level of integration due to supply chains also reflects variations or unique traits across individual ASEAN countries' economies. The availability and relative cost of labor are two important determinants of success in the clothing industry. It has been a trend to locate the more-labor-intensive clothing factories in the countries with relatively less-developed economies, such as Vietnam, Cambodia, and Laos, where labor costs are relatively low and a large pool of available labor exists. In contrast, production of more capital-intensive textiles (yarns and fabrics) and higher-quality apparel is concentrated in the ASEAN countries with higher labor costs, such as Thailand, Malaysia, and, to a lesser extent, Singapore. Cross-border integration is nurtured by investment from fabricproducing countries in ASEAN into the lower-cost-apparel manufacturing countries of Vietnam and Cambodia.

This study investigates the level of competitiveness among ASEAN countries in the textile and clothing industry as well as aims to understand what industry products possess comparative advantage and participate in intra-industry trade. By investigating the industry using product categories, the study will be able to reveal the countries and products that have trade-creating or trade-diverting effects, which would directly contribute to intra-regional trade. Furthermore, the study addresses an important subject that involves a key industry in the region. The textile and clothing industry in ASEAN countries faces fierce competition with that in China, Bangladesh, and India. Companies and factories operating in these latter countries are naturally supported under their respective value chains due to the larger business ecosystem. This means that smaller countries in ASEAN may lose out if integration within ASEAN in terms of value-chain creation fails.

Addressing this issue requires a deeper understanding of the status of intra-ASEAN trade, which is an integral part of building the value chain in the textile and clothing industry. Cross-border competition within the region for similar products may diminish intra-regional trade, especially when ASEAN countries also compete with each other to attract the same investors in the textile and clothing industry. By studying the nature of competiveness by product category among ASEAN countries more extensively, this study aims to determine the main structural trade issues that ASEAN countries must tackle. ASEAN countries can then use this knowledge to determine the products that are worth producing. Guiding countries by the nature of their natural competitiveness also offers a reality check on whether pursuing production of some products will be sustainable in the future. 


\section{Literature Review}

Among the earliest use of wide comparative advantage was the work by Balassa (1977). The study undertook an analysis of the pattern of competitive advantage of industrial countries for the period 1953 1971. The study observed an association between size and diversification of exports based on the standard deviation of different countries' Revealed Comparative Advantage (RCA) indices. The results showed that although the extent of export diversification tends to increase along with degree of technological development, a reversal takes place at higher levels.

Richardson \& Zhang (1999) used the Balassa RCA index and analyzed the patterns of trade in the United States across time, sectors, and regions. The differences were accounted for geographical proximity of trading partners, per capita income. More importantly, these factors vary over time and across sectors. The research also found that the high overall variability across regions in RCA indices seems unrelated to obvious explanations such as proximity or lingual or historical ties to the United States. At the same time, for producer goods, RCA variability across regions correlates somewhat better with accounts of trade diversion as well as regional preferences for and discrimination against US exports. They study also found little evidence of high or increasing variability across disaggregated commodity sub-groups in US RCA indices.

Tan (2005) specifically studied the effects of competitiveness and complementarities of ASEAN countries with China. His study explored the impact of trade liberalization in the textile and clothing industry in China on ASEAN countries for the period 1991 2003. The study found that ASEAN countries were more competitive than complementary in their relationship with China in this sector. Using a constant elasticity of substitution model, the study also found a significant negative effect of tariff elimination on ASEAN countries.

Whalley (2006) took a different approach by introducing the impact of eliminating trade restrictions under the Multi Fibre Arrangement (MFA) up to the end of 2004 for exports of clothing and textiles using data from the US, EU, China, and other main exporters. The results revealed an impact impact on the aggregate US and EU imports of clothing and textiles as well as an effect on the aggregate Chinese exports of clothing and textiles. However, it was observed that there were many changes in the countries' patterns of trade as well as within more narrowly defined product categories. Large increases were observed in shipments from China to both the US and EU, proportionally 
more so for the US in textiles than clothing. However, the US accounted for only $20 \%$ of China's clothing and textiles exports. Exports to Japan hardly changed, whereas exports to Hong Kong fell sharply. Large fall in price occurred in shipments to the US and certain EU countries (Germany). The shares of other Asian suppliers in US markets generally remained stationary, with the largest falls occurring in preferentially treated non-Asian suppliers such as Mexico. In EU markets, with the exception of India, all nonChinese Asian suppliers experienced a fall in their market share.

Pholphirul (2010) focused on examining whether AFTA creates trade for Thailand or in fact diverts it from the country. By using the Export Similarity Index (ESI), IntraIndustry Trade (IIT) index, and RCA rank correlation, the study revealed a high degree of similarity regarding the trade structures of Thailand and AFTA, which indicates that fewer trade-creation benefits will result from AFTA and a greater likelihood of trade diversion once the AFTA scheme has been fully implemented. This similarity pattern explains future collaboration among member countries and supportive arguments for future extension of ASEAN ( $A S E A N+)$. The study also suggested that Thai exporters accessing the ASEAN market should use market-penetration and development strategies.

Adhikari (2008) also examined the impact of a policy decision. He found that the post-quota world has not brought about a dramatic transformation in the textile and clothing market, or in sourcing patterns. Furthermore, among the losers of the post-quota era, not all are on the same footing. While some were able to graduate into production of higher-value products, others have lost out due to their lack of competitiveness and inability to adapt. The current status quo is the result of re-imposition of quotas on China as part of temporary safeguard measures agreed by the country at the time of its accession to the WTO. Countries that did not manage to withstand competition in the first six-month period after the phase-out of quotas needed to be extremely cautious and make every possible effort to enhance their competitiveness before the expiry of this temporary measure in 2008. Given the history of protection in the textile and clothing industry and rather strong political economy factors, market access remains the single largest problem facing developing countries. The study also identified several supply-side issues impeding the growth prospects of several developing countries. These problems need to be addressed first at the domestic level. Despite protectionist barriers, the textile and clothing industry has not remained static over the past five decades or so. It has continued to evolve due to changing buyer demands, sourcing patterns, and availability of and access to technology, as well as shifting levels of economic growth and increased consciousness. In addition, sensitivity toward corporate social responsibility and ethical 
procurement has also emerged as an influential element.

Berdine et al. (2008) examined how the US textile and apparel industry can remain competitive in the face of global competition. The study specifically considered the country's current competitive advantages and how they can be leveraged to enhance the performance of US textile and apparel companies. In addition, key components driving the competitiveness of the top textile and apparel exporting regions were examined in order to provide insight into how the US textile and apparel industry can adapt and compete. The research methodology used a concurrent triangulation strategy, which involves collecting quantitative and qualitative data simultaneously. Field-based fieldbased interviews were conducted with 20 executives from 13 companies. Key findings of this research include evidence that US textile companies drive the majority of the innovation in the supply chain to both suppliers and customers. Also, three competitive strategies that differentiate the products of US firms from those originating in other regions were identified: (1) research and development, (2) marketing, and (3) customer service.

Ilyas, Mukhtar, and Javed (2009) used the period 1985 2005 as the reference period to analyze competitiveness among Asian rice exporters in the global rice market using the Balassa RCA and White's Competitive Advantage (WRCA) over China in rice exports. No significant differences of revealed competitive advantage were found between Thailand and Vietnam or between India and Vietnam in agricultural product trade or between Pakistan and Vietnam in total merchandize trade. Pakistan was found to have revealed comparative advantages in agricultural product trade over all other countries and in total merchandize trade over China, India, and Thailand. Although Thailand and India are the two largest Asian exporters of rice with $47 \%$ of the market share in 2005 , they did not have the greatest comparative and competitive advantage in rice exports on average. Pakistan had the greatest advantage in rice exports, Vietnam ranked second, and Thailand ranked third out of five major Asian exporters. Thus, both Pakistan and Vietnam could take advantage of competitiveness and raise their respective shares in the global rice market compared with other Asian competitors.

$\mathrm{Au}$ and Chan (2003) examined the extent and determinants of intra-industry textile and clothing trade for OECD countries. Trade overlap was used to measure IIT. The general trend of intra-OECD trade and the extent of IIT for textile and clothing trade in the year 2000 were examined. Multiple regression analysis was employed to empirically verify the proposed country-specific determinants of bilateral IIT. Hypotheses relating to five country-specific variables were tested and found to show strong significance, 
reflecting the different roles the tested factors play in the determination of IIT. Bilateral IIT in textile and clothing between OECD countries were also found to be highly correlated.

Chemsripong (2010) applied the Grubel Lloyd indices for the 2000 2010 period for intra-ASEAN trade and found strong empirical support for the hypothesis that countries with common borders that have eliminated or lowered barriers on trade with each other will have relatively high levels of IIT. Moreover, the extent of IIT will be positively correlated with trade intensity. The level of IIT is higher between Malaysia, Singapore, and Indonesia compared to that with the rest of the world. Thailand's IIT was increasingly changing from low-technology products to high-technology industries.

Turkcan and Ates (2010) examined the composition of trade patterns and development of IIT for 367 trading partners in the automotive industry during 1989 2006. Trade patterns in the US automotive industry were analyzed by decomposing US autoindustry trade into inter-industry trade, horizontal IIT, and vertical IIT. Various countryspecific factors concerning the determinants of IIT and its components between the US and its major trading partners were tested empirically using the gravity model. Results showed that a substantial part of the US auto industry's IIT was vertical IIT, which was also found to increase over the data period. These increases indicated that international fragmentation of the production process has become important in the US auto industry. The econometric results mainly confirmed that determinants of horizontal IIT and vertical IIT differ. In particular, the extent of the US horizontal IIT in the automotive industry was found to be positively correlated with differences in per capita GDP and outward FDI variable, but negatively correlated with distance and bilateral exchange rates. In contrast, vertical IIT was positively associated with average market size, differences in market size, differences in per capita GDP, outward FDI, and distance but negatively correlated with the bilateral exchange rate variable.

Crinis (2012) examined Malaysia's garment industry from 1970 to 2011.The study considered strategies employed by manufacturers to cope with both the end of the MFA and the effects of the global economic crisis on the industry in Malaysia. Malaysia's garment industry is almost totally reliant on contracts with the US and Europe for its survival. Since the global economic recession, contraction in demand for garments in these countries had translated into factory closures and lay-offs in Malaysia. It was argued that a regional strategy is necessary to cope with increasing levels of competition from China and other parts of the world. 


\section{Methods}

The intra-regional trade effects in the textile and clothing industry for ASEAN-5 countries are investigated using IIT and RCA indices. The indices selected to analyze competitiveness and complementarities among ASEAN-5 countries were those that would yield a greater understanding of the nature of intra-regional trade in the textile and clothing industry within ASEAN.

IIT arises if a country simultaneously imports and exports similar types of goods or services. The classification of the goods or services in the same sector reflects similarities in the nature of the concerned goods or services. IIT reflects growth in intra-regional trade blocs and benefits generated from trade by increasing product variety. A country engaged in high levels of IIT can, for instance, concurrently reduce the number of products it produces and increase the variety of goods available to domestic consumers. In order to produce fewer varieties, a country can produce each variety of goods on a large scale with higher productivity and lower costs. Therefore, IIT tends to be apparent between countries that possess similar factor endowments. Gains from trade will be large when economies of scale are strong and products are highly differentiated.

Both economies of scale and product differentiation are essential for understanding IIT trade patterns. In particular, this study uses the index introduced by Grubel and Lloyd (1975) that measures IIT levels. This measure, known as the Grubel-Lloyd index (GL index), is intuitively appealing. Once a country's export and import values for a particular sector and period are known, it is calculated as

$$
I I T_{i j}=\frac{\left|X_{i j}-M_{i j}\right|}{X_{i j}+M_{i j}}
$$

where,

$X_{i j}$ is the value of country $i$ 's exports of product $j$ to the market under investigation and $M_{i j}$ is the value of the country's imports of product $j$ from the market being examined

When no intra-trade occurs within a given industry, it is expected that a country will either export or import goods from that industry, not both, in which case, the IIT index would be equal to 0 . In contrast, if a country's exports and imports within an industry were equal, the IIT index would equal 1. The IIT index is calculated for the three 
separate industries at the HS3-level classification to ensure that data are more accurate in representing product-level items.

The second approach is to investigate the RCA. Conventional thinking on FTAs maintains that potential gains from an FTA depend on whether the trade pattern between two countries in the FTA is complementary or substitutable. An RCA index measures the competitiveness of countries' industries in the global market. An RCA index is a standard approach or methodology to estimate a country's comparative advantage or comparative disadvantage in commodities, industries, or sectors. Based on Ricardian theory, comparative advantage occurs due to technological dissimilarities across nations, whereas the $\mathrm{H}-\mathrm{O}$ theory considers cost dissimilarities arising due to differences in factor prices across nations, assuming constant technology. In this regard, it can be summarized that trade theories in classical context are based on pre-trade relative price differences across countries.

In general, if the index is above 1, the country has comparative advantage and, when the index is below 1, the country has comparative disadvantage. To ensure that this model is fit for the purpose of analyzing intra-ASEAN trade, this study employs a formula based on the basic RCA formula given above. This formula aims to show the extent to which ASEAN members are competing in the ASEAN market; it will also show the degree of competitiveness exhibited by each ASEAN country in selected ASEAN markets for the textile and clothing industry. The formula is as follows:

$$
R C A_{i j}=\left(X_{i j m} / X_{i t m}\right) /\left(X_{a w j} / X_{a w t}\right)
$$

where;

$X_{i j m}$ is exports of product $j$ by country $i$ to market under investigation;

$X_{i t m}$ is total exports of country $i$ to market under investigation;

$X_{a w j}$ represents ASEAN's exports of product $\mathrm{j}$ to the world; and

$X_{a w t}$ represents total ASEAN's exports to the world

For both IIT and RCA indices, data are collected from materials published by International Trade Centre in Geneva, which collects data from UNCOMTRADE (International Trade Centre 2015). The data collected are for the ASEAN-5 countries for the period 2001 2014. The types of data include individual ASEAN-5 values for exports and imports to and from individual ASEAN-5 countries. The data are collected at HS4 


\section{Table 4. Reclassified HS4 Products}

\begin{tabular}{|c|c|c|}
\hline HS3 Level & Products & HS4 Combinations \\
\hline 430 & $\begin{array}{l}\text { Furskins raw, tanned or dressed and } \\
\text { artificial apparel and furs }\end{array}$ & $4301,4302,4303,4304$ \\
\hline 500 & Raw silk and silk yarn & $5001,5002,5003,5004,5005,5006,5007$ \\
\hline 510 & Raw wool, wool yarn and animal hairs & $\begin{array}{l}\text { 5101, 5102, 5103, 5104, 5105, 5106, 5107, } \\
5108,5109\end{array}$ \\
\hline 511 & $\begin{array}{l}\text { Woven fabrics of wool or animal hair } \\
\text { carded or combed }\end{array}$ & $5110,5111,5112,5113$ \\
\hline 520 & Cotton, cotton yarn and woven cotton & $\begin{array}{l}5201,5202,5203,5204,5205,5206,5207, \\
5208,5209\end{array}$ \\
\hline 521 & Woven fabrics of cotton & $5210,5211,5212$ \\
\hline 530 & $\begin{array}{l}\text { Flax raw, hemp, jute, vegetables, yarn of } \\
\text { jute and vegetables }\end{array}$ & $\begin{array}{l}5301,5302,5303,5304,5305,5306,5307, \\
5308,5309\end{array}$ \\
\hline 531 & Woven fabrics of jute, vegetable fibre & 5310,5311 \\
\hline 540 & $\begin{array}{l}\text { Man-made:filaments yarn and synthetic } \\
\text { yarn }\end{array}$ & $\begin{array}{l}5401,5402,5403,5404,5405,5406,5407, \\
5408\end{array}$ \\
\hline 550 & $\begin{array}{l}\text { Synthetic and artificial: filament tow, } \\
\text { staple fibres }\end{array}$ & $\begin{array}{l}5501,5502,5503,5504,5505,5506,5507, \\
5508,5509\end{array}$ \\
\hline 551 & $\begin{array}{l}\text { Staple fibre; man made yarn, woven } \\
\text { fabrics }\end{array}$ & $5510,5511,5512,5513,5514,5515,5516$ \\
\hline 560 & $\begin{array}{l}\text { Wadding of textiles, rubber thread, } \\
\text { metalized and gimped yarn etc }\end{array}$ & $\begin{array}{l}5601,5602,5603,5604,5605,5606,5607, \\
5608,5609\end{array}$ \\
\hline 570 & Carpets and other textile floor covering & $5701,5702,5703,5704,5705$ \\
\hline 580 & $\begin{array}{l}\text { Woven, pile \& chenille fabrics, } \\
\text { towelling, gauze, tulles, label, etc }\end{array}$ & $\begin{array}{l}5801,5802,5803,5804,5805,5806,5807, \\
5808,5809\end{array}$ \\
\hline 581 & $\begin{array}{l}\text { Embroidery in the piece of strips or in } \\
\text { motifs }\end{array}$ & 5810,5811 \\
\hline 590 & $\begin{array}{l}\text { Textile fabrics ctd, nylon etc, linoleum } \\
\text { etc, text wall, rubberized text etc. }\end{array}$ & $\begin{array}{l}5901,5902,5903,5903,5904,5905,5906, \\
5907,5908,5909\end{array}$ \\
\hline 591 & $\begin{array}{l}\text { Transmission or conveyor belts; text } \\
\text { prod \& articles for tech use }\end{array}$ & 5910,5911 \\
\hline 600 & Fabrics, knitted/crocheted & $6001,6002,6003,6004,6005,6006$ \\
\hline 610 & $\begin{array}{l}\text { Women and man: coat,jacket, suits, } \\
\text { undergarments, knitted/croch etc }\end{array}$ & $\begin{array}{l}\text { 6101, 6102, 6103, 6104, 6105, 6106, 6107, } \\
6108,6109\end{array}$ \\
\hline 611 & $\begin{array}{l}\text { Jerseys, babies garments, track suits, } \\
\text { swimwear kintted/croch etc }\end{array}$ & $\begin{array}{l}\text { 6110, 6111, 6112, 6113, 6114, 6115, 6116, } \\
6117\end{array}$ \\
\hline 620 & $\begin{array}{l}\text { Women and man:overcoat, jacket, } \\
\text { dresses, undergarments etc }\end{array}$ & $\begin{array}{l}6201,6202,6203,6204,6205,6206,6207, \\
6208,6209\end{array}$ \\
\hline 621 & $\begin{array}{l}\text { Track suits, ski suits and swimwear, } \\
\text { handkerchief, tie, gloves etc }\end{array}$ & $\begin{array}{l}6210,6211,6212,6213,6214,6215,6216, \\
6217\end{array}$ \\
\hline 630 & $\begin{array}{l}\text { Blankets and travelling rugs, bed, table, } \\
\text { curtains, sacks and bags, tents }\end{array}$ & $\begin{array}{l}\text { 6301, 6302, 6303, 6304, 6305, 6306, 6307, } \\
6308,6309\end{array}$ \\
\hline 631 & Rags, scrap twine, cordage, rope & 6310 \\
\hline 640 & Footwear & $6401,6402,6403,6405,6406$ \\
\hline 650 & Hat and Headgear etc & $6501,6502,6503,6504,6505,6506,6507$ \\
\hline
\end{tabular}

(Source) Author's own illustration 
level and then combined to form HS3-level data to provide more accurate results. Table 4 shows the reclassification of product categories to the HS3 level. Exports from each individual ASEAN-5 country to the world are also obtained from the same source.

\section{Figure 2. Bilateral pairs of countries}

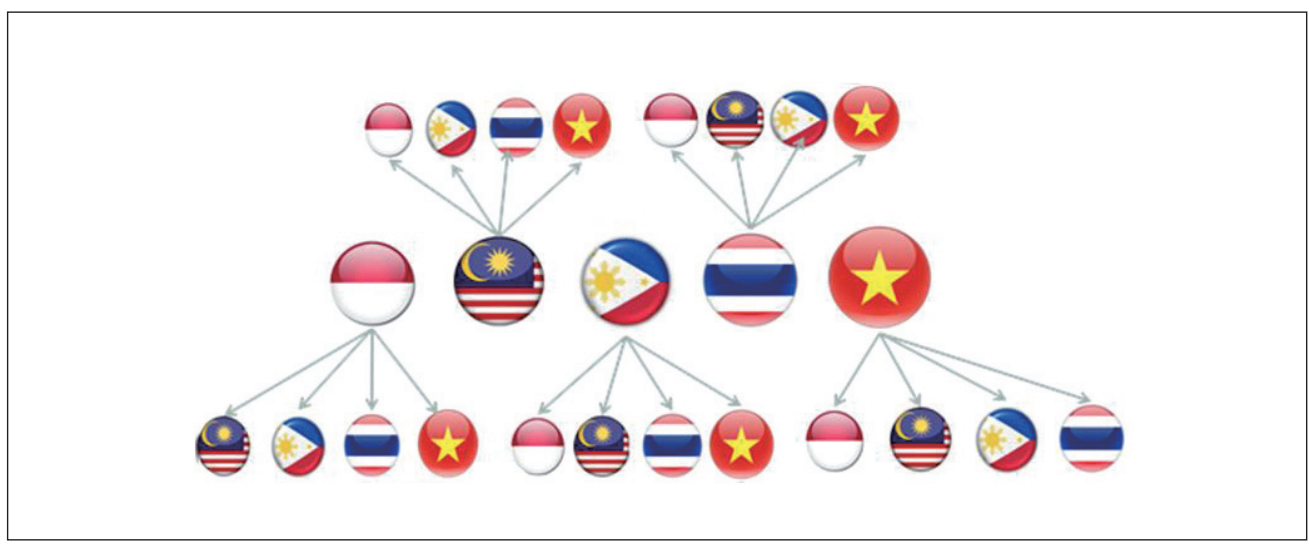

(Note) The bilateral pairs of ASEAN-5 countries are indicated by the flag logos above. The mid-section logos indicate Indonesia, Malaysia, the Philippines, Thailand, and Vietnam (in order from left). Each of these countries is tested against the other four countries for RCA and IIT values, providing a detailed intra-ASEAN investigation using bilateral pairs. The above figure shows the 20 bilateral pairs that were investigated.

(Source) Author's own illustration

Next, to investigate the relationship at the intra-ASEAN level, both indices are estimated for five ASEAN countries, namely, Indonesia, Malaysia, Thailand, Philippines, and Vietnam. These countries were chosen based on their involvement in AFTA, and unlike many other studies that include Brunei and Singapore, Vietnam was chosen to replace these countries. Brunei was excluded because its trade value for all products is very low, and inclusion of Singapore as a free-trade port would distort the actual benefit of AFTA because it would not represent the benefits of AFTA.

In addition, the study uses a unique and new technique to investigate RCA and IIT by analyzing 20 bilateral pairs of ASEAN-5 countries as shown in Figure 2. This method is more meaningful because it investigates each country in terms of another country, thus revealing trends throughout the period of investigation. A total of 1,040 observations are made. 
The technique used in this study is quite unique and it must be emphasized that firm-level data are lacking for ASEAN economies. Thus, trade-flow data and use of the two indices comprise the most accurate way of investigating the competitiveness and complementarities among ASEAN countries. This study investigate the textile and clothing industry in isolation from other supporting industries, and conducting the investigation at the HS3 level will provide a more accurate picture of trade flows among ASEAN countries in the textile industry. Other factors such as national industrial competitiveness, resource allocation, macroeconomics, and market orientation would distort the study's results because this study focuses on intra-regional trade; using the two indices gives a balanced comparison based on trade flows.

\section{Results}

\section{A. Intra-industry trade}

Overall IIT values by country showed very few significant values. The majority of product categories did not display significant IIT values, which suggests that ASEAN countries remained focused on inter-industry trade in the textile and clothing industry. This situation may occur when the market is less diversified, thus suggesting lower integration between economies in AFTA.

As shown in Table 5, some of the significant IIT values varied across product categories and country. Significant IIT values for Malaysia were recorded with Thailand and Indonesia only. However, products in HS560 recorded significant values for both Thailand and Indonesia. This indicates high two-way Malaysia-Thailand and MalaysiaIndonesia trade for products in HS560.

Both Indonesia-Thailand and Thailand-Indonesia also showed significant IIT values for several product categories. Both pairs recorded significant values for HS520 and HS521. This also suggests that Indonesia and Thailand have the highest number of product categories with significant IIT values. Nevertheless, when all IIT values for the textile and clothing industry are observed, it is clear that intra-industry trade only exists dominantly for Malaysia, Thailand, and Indonesia. The product categories covered show that high level of two-way trade occurs between these countries, as shown in Table 5. 
Table 5. Product Categories with significant IIT values

\begin{tabular}{|c|c|c|}
\hline Country & HS Code & Pair Country \\
\hline \multirow{4}{*}{ Malaysia } & 540 & Thailand \\
\cline { 2 - 3 } & 560 & Thailand \\
\cline { 2 - 3 } & 591 & Thailand \\
\cline { 2 - 3 } & 560 & Indonesia \\
\hline \multirow{4}{*}{ Indonesia } & 630 & Indonesia \\
\cline { 2 - 3 } & 520 & Thailand \\
\cline { 2 - 3 } & 521 & Thailand \\
\cline { 2 - 3 } & 580 & Thailand \\
\hline \multirow{5}{*}{ Thailand } & 610 & Thailand \\
\hline \multirow{4}{*}{} & 520 & Indonesia \\
\cline { 2 - 3 } & 521 & Indonesia \\
\cline { 2 - 3 } & 580 & Indonesia \\
\cline { 2 - 3 } & 610 & Indonesia \\
\hline \multirow{4}{*}{ Vietnam } & 620 & Thailand \\
\hline
\end{tabular}

(Source)Author's own illustration

\section{B. Revealed comparative advantage}

As shown in Table 6, Malaysia exhibits competitiveness in terms of all four ASEAN countries for the textile and clothing industry. The number of product categories with a significant RCA index value was highest in the Indonesian market. Seven product categories showed a significant RCA index value, and three product categories did not have any competing country, namely, HS521, HS591, and HS630. This shows that Malaysia has gained a clear comparative advantage in this product category for the Indonesian market.

This is then followed by products in HS430, which recorded one competing country, and HS600, with two competing countries. Products of HS560 and HS580 both face intense competition with other ASEAN countries, with three competing countries in the Indonesian market. 
Table 6. Significant RCA index: Malaysia-ASEAN

\begin{tabular}{|c|c|c|c|}
\hline Country & HS Code & Pair Country & $\begin{array}{c}\text { Competing } \\
\text { countries }\end{array}$ \\
\hline \multirow{4}{*}{} & 430 & Thailand & 1 \\
\cline { 2 - 4 } & 510 & Indonesia & 0 \\
\cline { 2 - 4 } & 521 & Indonesia & 0 \\
\cline { 2 - 4 } & 560 & Indonesia & 3 \\
\cline { 2 - 4 } & 580 & Indonesia & 3 \\
\cline { 2 - 4 } & 591 & Indonesia & 0 \\
\cline { 2 - 4 } & 600 & Indonesia & 2 \\
\cline { 2 - 4 } & 630 & Indonesia & 0 \\
\cline { 2 - 4 } & 631 & Indonesia & 1 \\
\cline { 2 - 4 } & 560 & Philippines & 1 \\
\cline { 2 - 4 } & 630 & Philippines & 0 \\
\cline { 2 - 4 } & 521 & Vietnam & 2 \\
\cline { 2 - 4 } & 540 & Vietnam & 2 \\
\cline { 2 - 4 } & 551 & Vietnam & 2 \\
\cline { 2 - 4 } & 560 & Vietnam & 2 \\
\cline { 2 - 4 } & 600 & Vietnam & 0 \\
\hline
\end{tabular}

(Source)Author's own illustration

Malaysia also recorded RCA without any competing countries for products in HS630 in the Philippines market and products in HS600 in the Vietnamese market. It was also observed that for the Vietnamese market, Malaysia faced steep competition from other ASEAN countries. Gaining comparative advantage when facing strong competition in a growing market like Vietnam requires Malaysia to compete with other countries, and the trend shows that Malaysia has displayed increasing RCA values for products in HS521 and a decreasing trend for products in HS540 in the Vietnamese market. 
Table 7. Significant RCA index: Thailand-ASEAN

\begin{tabular}{|c|c|c|c|}
\hline Country & HS Code & Pair Country & $\begin{array}{l}\text { Competing } \\
\text { countries }\end{array}$ \\
\hline \multirow{23}{*}{ Thailand } & 560 & Malaysia & 0 \\
\hline & 570 & Malaysia & 1 \\
\hline & 590 & Malaysia & 2 \\
\hline & 600 & Malaysia & 0 \\
\hline & 550 & Indonesia & 0 \\
\hline & 560 & Indonesia & 3 \\
\hline & 580 & Indonesia & 3 \\
\hline & 590 & Indonesia & 1 \\
\hline & 600 & Indonesia & 2 \\
\hline & 540 & Philippines & 1 \\
\hline & 550 & Philippines & 2 \\
\hline & 560 & Philippines & 1 \\
\hline & 570 & Philippines & 0 \\
\hline & 581 & Philippines & 0 \\
\hline & 430 & Vietnam & 0 \\
\hline & 520 & Vietnam & 1 \\
\hline & 521 & Vietnam & 1 \\
\hline & 540 & Vietnam & 2 \\
\hline & 550 & Vietnam & 1 \\
\hline & 551 & Vietnam & 2 \\
\hline & 560 & Vietnam & 2 \\
\hline & 580 & Vietnam & 1 \\
\hline & 581 & Vietnam & 0 \\
\hline
\end{tabular}

(Source) Author's own illustration 
Table 8. Significant RCA index: Indonesia-ASEAN

\begin{tabular}{|c|c|c|c|}
\hline Country & HS Code & Pair Country & $\begin{array}{c}\text { Competing } \\
\text { countries }\end{array}$ \\
\hline \multirow{27}{*}{ Indonesia } & 520 & Malaysia & 1 \\
\hline & 521 & Malaysia & 0 \\
\hline & 540 & Malaysia & 0 \\
\hline & 551 & Malaysia & 0 \\
\hline & 570 & Malaysia & 1 \\
\hline & 590 & Malaysia & 2 \\
\hline & 631 & Malaysia & 1 \\
\hline & 540 & Thailand & 1 \\
\hline & 551 & Thailand & 0 \\
\hline & 580 & Thailand & 1 \\
\hline & 590 & Thailand & 1 \\
\hline & 600 & Thailand & 0 \\
\hline & 520 & Philippines & 1 \\
\hline & 521 & Philippines & 0 \\
\hline & 540 & Philippines & 1 \\
\hline & 550 & Philippines & 2 \\
\hline & 590 & Philippines & 1 \\
\hline & 520 & Vietnam & 1 \\
\hline & 521 & Vietnam & 2 \\
\hline & 540 & Vietnam & 2 \\
\hline & 550 & Vietnam & 1 \\
\hline & 551 & Vietnam & 2 \\
\hline & 560 & Vietnam & 2 \\
\hline & 570 & Vietnam & 0 \\
\hline & 590 & Vietnam & 0 \\
\hline & 600 & Vietnam & 1 \\
\hline & 631 & Vietnam & 0 \\
\hline
\end{tabular}

(Source) Author's own illustration 
Table 9. Significant RCA index: Philippines-ASEAN

\begin{tabular}{|c|c|c|c|}
\hline \multirow{2}{*}{ Country } & HS Code & Pair Country & $\begin{array}{c}\text { Competing } \\
\text { countries }\end{array}$ \\
\hline \multirow{4}{*}{ Philippines } & 631 & Malaysia & 1 \\
\cline { 2 - 4 } & 580 & Thailand & 1 \\
\cline { 2 - 4 } & 631 & Thailand & 0 \\
\cline { 2 - 4 } & 530 & Indonesia & 1 \\
\cline { 2 - 4 } & 560 & Indonesia & 3 \\
\cline { 2 - 4 } & 580 & Indonesia & 1 \\
\cline { 2 - 4 } & 631 & Indonesia & 1 \\
\hline
\end{tabular}

(Source) Author's own illustration

As shown in Table 7, Thailand showed RCA values without any competing countries for seven categories. Products in HS560 recorded significant RCA values for all pair countries; however, in the Malaysian market, Thailand emerged as the only country with a significant RCA value for products in HS560. Thailand also recorded significant values without competition for two product categories in the Philippines. In the Indonesian and Vietnamese markets, Thailand faced competition from other ASEAN countries in some product categories.

Significant RCA values were also found for many product categories in Indonesia, most of which were competing with other ASEAN countries. However, Indonesia recorded the highest number of product categories with a sole significant RCA value with ASEAN countries. The product categories were mostly apparent between Indonesia and Vietnam. Indonesia also had nine product categories without any competing countries. For products in HS590, Indonesia recorded a significant RCA index with all ASEAN countries. As shown in Table 8, Indonesia has the highest number of product categories, 24 in number, among ASEAN countries, . 
Table 10. Significant RCA index: Vietnam-ASEAN

\begin{tabular}{|c|c|c|c|}
\hline Country & HS Code & Pair Country & $\begin{array}{c}\text { Competing } \\
\text { countries }\end{array}$ \\
\hline \multirow{19}{*}{ Vietnam } & 520 & Malaysia & 1 \\
\hline & 550 & Malaysia & 0 \\
\hline & 590 & Malaysia & 2 \\
\hline & 430 & Thailand & 1 \\
\hline & 500 & Thailand & 0 \\
\hline & 540 & Thailand & 1 \\
\hline & 590 & Thailand & 1 \\
\hline & 630 & Thailand & 0 \\
\hline & 511 & Indonesia & 0 \\
\hline & 530 & Indonesia & 1 \\
\hline & 540 & Indonesia & 0 \\
\hline & 560 & Indonesia & 3 \\
\hline & 580 & Indonesia & 3 \\
\hline & 590 & Indonesia & 1 \\
\hline & 600 & Indonesia & 2 \\
\hline & 520 & Philippines & 1 \\
\hline & 550 & Philippines & 2 \\
\hline & 590 & Philippines & 1 \\
\hline & 600 & Philippines & 0 \\
\hline
\end{tabular}

(Source) Author's own illustration

Philippines recorded significant RCA values only for a few items. Especially, comparative advantage was found for products in HS631 in comparison with Malaysia, Thailand, and Indonesia. RCA index for the Philippines for this product category showed no country as a competitor for the Thailand market. Philippines' RCA index in the Indonesia's market was the most competitive because their product categories with a significant RCA index were competing with other ASEAN countries. 
For Vietnam, many product categories were found with significant RCA values with all four other ASEAN countries. As shown in Table 10, most of the significant RCA index values were recorded in the Indonesian market, and Vietnam seemed to compete with other ASEAN countries. However, Vietnam managed to display comparative advantage without any competing country for products in HS511 and HS540 in the Indonesian market. Vietnam also faced competition in the Malaysian and Thai markets.

\section{Summary}

Overall, a significant number of product categories with high RCA index values was found for the textile and clothing industry in ASEAN countries, which shows that ASEAN countries have been able to capture certain markets within ASEAN. There were also many product categories that, despite showing significant RCA values, were competing with one or more ASEAN countries. This shows that ASEAN countries to some extent are competing in the same product categories in the same markets. This is more evident when one pair of these competing countries shows an increasing trend and the other pair shows a decreasing trend.

In terms of the individual countries, Indonesia recorded the highest number of product categories with significant RCA values, whereas Philippines recorded the least. It can be observed that Indonesia and Vietnam offered the largest range of product categories with significant RCA values. The levels of RCA among these countries suggest that AFTA might have a wide ramification of integrating the countries under investigation. Besides the Philippines, all other ASEAN countries managed to at least have one product category with an RCA value with respect to which they were not competing with any other ASEAN country. However, deep competition still exists between ASEAN countries in certain product categories, although the similarities among these product categories were not very apparent.

The results of both RCA and IIT for the textile and clothing industry shows that most ASEAN countries compete and trade with each other mostly in unprocessed products or raw materials because the RCA values recorded for these product categories were significant. Product categories with finished or consumer goods for the clothing industry do not show high degrees of competition among ASEAN countries, although the value of trade in these products was high. ASEAN countries trade less with each other because most of these products produced in ASEAN countries are exported to the global market. 
Two-way trade still exists among ASEAN countries for those product categories, as reflected by significant IIT values. The significant RCA values recorded for unprocessed products are as follows:

\section{Products in HS520: cotton, cotton yarn, and woven cotton}

For products in HS520, which mostly involve cotton, cotton yarn, and woven cotton, three countries in ASEAN show significant RCA values. The main importers of products in this category are Vietnam, Malaysia, and the Philippines. High degree of competition exists between Indonesia and Thailand for the Vietnamese market. The trend shows that Thailand began losing its competitiveness to Indonesia after 2005. Indonesia has also shown an increasing trend for RCA values for the Malaysian and Philippine markets.

\section{Products in HS540: man-made filaments yarn and synthetic yarn}

Similar to the products in HS520, product in HS540, which mainly involve manmade filaments yarn and synthetic yarn, demonstrated high degrees of competition among Indonesia, Vietnam, and Thailand. In the period 2001 2005, Thailand recorded significant RCA values for the Vietnam and Philippines markets, but started to lose competitiveness, especially to Indonesia, which gained competitiveness in the same markets after 2005 .

\section{Products in HS550: synthetic and artificial: filament tow and staple fibers}

Thailand, Indonesia, and Vietnam showed high degree of competition among each other for products of HS550, namely, synthetic and artificial filament tow and staple fibers. The trend shown by these three countries seems to fluctuate, and only Thailand's RCA value remained significant for the whole period.

\section{Trade effects}

The results for the textile and clothing industry by product category can be summarized as follows: 


\section{High level of integration: trade creation}

Products in HS520, 521, 560, and 580, although recording lower value of exports between ASEAN countries, showed trade-creating effects, with significant RCA values and high IIT values between countries. Malaysia, Thailand, Indonesia, and Vietnam showed this trade-creating effect

\section{High degree of competition: Trade diversion}

Products in HS520, HS540, and HS550 are higher-value exports for low processed or raw products for the textile industry. The results show that a high degree of competition exists among ASEAN countries, particularly between Thailand and Indonesia, where Thailand has lost some of its competitiveness to Indonesia.

\section{Low level of integration or isolation}

Products with high export values that are processed, mainly apparel and clothing, such as products in HS610, HS611, HS620, HS621, and HS640, did not show any sign of competitiveness for any ASEAN country in ASEAN markets. The IIT values for these product categories were also low, suggesting that integration between ASEAN countries for these products was very low. This can be attributed mainly to the fact that ASEAN countries continue to export their finished products in the textile and clothing industry to markets outside ASEAN.

\section{Discussion}

The textile and clothing industry showed two types of results. The first type concerns the competitiveness of ASEAN countries vis-a-vis each other for low processed or raw products, which are mainly represented by product in HS520, HS540, and HS550. In contrast, other product categories, mainly clothing, apparel, and finished products, which are represented by products in HS610, HS611, HS620, HS621, and HS640 with high export values, did not show any level of competitiveness among ASEAN countries. Although some existing intra-industry trade between Thailand and Indonesia was found, 
other pair of countries did not show significant RCA or IIT values.

ASEAN countries today are already seen as a formidable force in the textile and clothing industry. However, the growing industry in ASEAN faces steep competition with China, and competition is most prevalent with respect to low-cost production, which comes with low labor costs. These factors of competitiveness in ASEAN will not be sustainable without sound policy judgments by ASEAN countries to compete and gain comparative advantage against their main external competitor, China. At the same time, ASEAN countries also need to build their capacity to face technical changes occurring in the industry.

Many of the textile industries in ASEAN compete with each other in terms of upstream products, and this competition intensifies when China is included. ASEAN countries need to move away from their dependence on foreign-owned firms that mostly take advantage of low labor costs to enter the cheaper-labor ASEAN market. Although these investments certainly spurred these countries' economic growth, industries driven by foreign companies alone will not be sustainable. This has been the case for Vietnam and Cambodia, where thousands of foreign-owned companies were established in the textile and clothing industry. Such investments may not last long because competition may arise, especially with China, and the risk of technology change, which could cause the entire industry in ASEAN countries to collapse. To mitigate these risks, governments in ASEAN countries should develop their own industry players by providing incentives or loans to allow local firms to compete with foreign companies. Skills and end-user fashion and design must also be developed locally to enhance the local quality and design of products. More local participation in the industry, especially within SMEs, would enable these ASEAN countries to have the local champions and avoid overdependence on foreign-owned firms.

This study have shown, ASEAN countries possess different strengths and weaknesses for each product category. These strengths and weaknesses must be taken into consideration to ensure that ASEAN is fully integrated in this industry through an integrated supply chain. Currently, however, the low IIT for finished products, as well as the general intra-ASEAN trade for the textile industry, requires a boost from individual policymakers to move away from the sentiment of protecting the industry and competing with neighbors. At the same time, industry players must be discouraged from attempting to complete the entire production process in a single country. These sentiments and perceptions may cost ASEAN countries their already-tenuous comparative advantage. Industry players that think regionally are set to be in a better position by harnessing 
the strengths of different ASEAN countries. These efforts would be achievable only with improved tariff elimination and trade facilitation, coupled with trade promotion, increased investments in productivity, and improved skills.

Moving away from national protectionist approaches for this industry, countries need to eliminate tariffs more rapidly and remove items that are still on the exclusion list. Besides tariff elimination or reduction, the industry also depends on the Rules of Origin (ROO). A full review of textile and clothing ROO and regional accumulation rules need to be conducted before entering into regional trade agreements with other parties. ASEAN's move to sign several FTAs with its dialog partners and its ambition of completing the Regional Comprehensive Economic Partnership (RCEP) should be based on ROO that have been standardized and should facilitate intra-ASEAN trade. Failure to achieve this would negatively impact ASEAN's strength as a single trading bloc given the lower intra-ASEAN trade value recorded in this industry.

The survival of the textile industry in ASEAN will be highly dependent on how countries in the region manage changes occurring in the industry, particularly their ability to follow a balanced and sequenced approach. AFTA provided the necessary platform for ASEAN countries to liberalize trade, but, the pace of development and national agendas must also be taken into account. Cognizant of the scale and capability of larger countries that compete with ASEAN countries, it is important for ASEAN to act as a bloc to be competent in the textile industry.

As this study has shown, ineffective competition among ASEAN countries occurs mainly in unprocessed products or raw materials. Smaller businesses that focus on these products should be given more importance, and this area should be explored further for vertical integration. The main issue this study found was that competition in these product categories shows that some countries compete within ASEAN and focus on supplying products to China. Although exporting products to China might be beneficial in the short term, it will not be sustainable in the long term. ASEAN countries should be focusing on expanding the range of finished products in which they have comparative advantage and, at the same time, invest in technology and research to be more efficient than their larger competitors in the region. With better infrastructure developments among ASEAN countries and cross-border connectivity, a complete and more effective supply chain can be fully realized.

This study also revealed that ASEAN countries compete with each other intensely in upstream products, which shows the existence of inefficient competition among ASEAN countries in such product categories. This involves the process of producing fiber, yarn, 
and fabric, which includes financing the manufacturing processes. Some countries examined in this study, such as Thailand, Indonesia, and Malaysia, revealed comparative advantage in man-made fiber products. However, competing with each other in the same market, such as that found in Vietnam, reduces the opportunity for vertical integration. These ASEAN countries should focus on expanding their current finished products toward vertical integration.

ASEAN countries also face the challenge of moving up the scale in products such as cotton, yarn, and staples, even if the issue of competition between ASEAN countries is somewhat resolved. Countries like China and Taiwan are way ahead in terms of cost, quality, and volume. Producers in ASEAN are very much small and do not have the ability to compete with these established players. In order for ASEAN to rise to this challenge, scale will play an important role. Investments in the textile and clothing industry should be focused in developing areas where production of input materials can be emphasized to reduce dependence on input products from China or Taiwan. This will require a concerted effort by ASEAN countries to reduce all tariff barriers, to improve connectivity, and to boost investment in technology.

Received 4 June 2017, Revised 11 July 2017, Accepted 4 August 2017

\section{References}

$\mathrm{Au} \mathrm{KF}$ and Chan YH, "Determinants of intra-textile and clothing trade: The case of OECD countries" Journal of Textile and Apparel, Technology \& Management, 3(1) (2003) , 1-12

Bela Balassa, Revealed Comparative Advantage Revisited: An Analysis of Relative Export Shares of Industrial Countries, 1953 - 1971",." The Manchester School of 
Economic\& Social Studies , 1977). 45 (4), 327-344.

Bela Balassa, Trade Liberalization and Revealed Comparative Advantage. (Manchester School of Economic and Social Studies, 1965).

D. Richardson, and C. Zhang, "Revealed Comparative Advantage: Chaotic or Coherent Patterns Across Time and Sector and U.S Trading Partner?” National Bureau of Economic Research (1999),Working Paper No: 7212.

George Siy, “ASEAN Textile and Garment Industry Outlook" Confederation of Garments Exporters of the Philippines (2007)

Grubel, H. G. and Lloyd, P. "Intra-Industry Trade: The Theory and Measurement of International Trade in Differentiated Products”. (London, MacMillan, 1975)

International Trade Centre. (2015, August 15). ITC- Trade Map. Retrieved August 18, 2015 from Trade Map: www.intracen.org/tradestat

J.C. Tan, "The Liberalisation of Trade in Textile and Clothing China's Impact on the ASEAN Economies" (2005), Stanford University, Department of Economics.

John Whalley , "The Post MFA Performance of Developing Asia", NBER Working Paper No. 12178 (2006).

Matt Berdine, "Measuring the Competitive Advantage of the US Textile and Apparel Industry," Industry Studies Conference Paper (2008)

Muhammad Ilyas, Tahir Mukhtar and Muhammad Tariq Javed, "Competitiveness among Asian Exporters in the World Rice Market", The Pakistan Development Review(2009), 48, Issue 4

Pär Hansson, "Intra-Industry Trade: Measurements, Determinants and Growth." (Ume University, Solfjärden AB,1989)

Paul Krugman, Growing World Trade: Causes and Consequences. (Brookings,1995). Piriya Pholphirul, "Does AFTA Create More Trade for Thailand? An Investigation of Some Key Trade Indicators.” Journal of Current Southeast Asian Affairs (2010), 29 (1), 51-78. 
Sujinda Chemsripong "Regional Integration and Intra-Industry Trade in Manufactures between Thailand and Other APEC Countries," The Singapore Economic Review (2009), Vol. 54, No. 1, 2009, 135-148.

Turkcan K. and Ates, A., "Structure and Determinants of Intra-industry Trade in the U.S. Auto-Industry", Journal of International and Global Economic Studies, (2010) 2(2): $15-46$.

V.D Crinis, "Global commodity chains in crisis: the garment industry in Malaysia", Institutions and Economies (2012), vol. 4, no. 3, pp. 61-82. 